\section{Britain ponders joining European collaboration}

FAST breeder reactors are not dead in Britain, where the government seems to have turned down a plan to collaborate with the United States and to have turned to France instead. The plan seems to be to mount a collaborative development programme involving France, Britain, Belgium, Italy, the Netherlands and West Germany. But final agreement has not yet been reached.

The French fast breeder programme is now occupied with the construction of Superphenix, at 1,200 MWe the world's largest fast reactor. Superphénix should switch on in 1984, but the French and their partners have a problem with what to do next. Nobody, least of all the French, needs more electricity at present, so there is no market for the commercial demonstration fast reactors (CDFRs) that should succeed

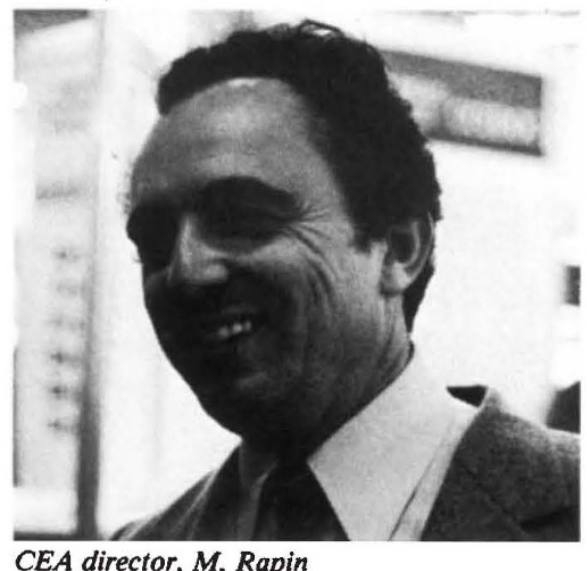

CEA director, $M$. Rapin

Superphénix (except for a small military market for plutonium). Classing the reactors as part of a development programme, and sharing costs and expertise with the British, who have a long-standing fast research programme at Dounreay in northern Scotland, makes sense in France.

M. Michel Rapin, director of the technical research and industrial development wing of the Commissariat á l'Energie Atomique (CEA), is responsible for Superphénix and its successors. According to Rapin, "technical people" on both sides of the English Channel "now think we are very near an agreement". CEA had discussed cooperation with the United Kingdom Atomic Energy Authority (AEA) (which runs Dounreay) in 1979 and 1980 without success, but last year discussions began again after the matter had been brought up at a meeting between Prime Minister Margaret Thatcher and President François Mitterrand. This time the discussions went better. "Now it's a political matter", says Rapin.

In Britain, AEA admits it has recommended a foreign partner to the government - but coyly will not say which. The recommendation follows a request last November by $\mathrm{Mr}$ Nigel Lawson, then Secretary of State for Energy, to the AEA chairman, Sir Peter Hirsch, to submit plans for a rationalization of the British fast breeder programme. There would be no series orders for fast breeders before the next century, Mr Lawson said, so the research programme should be trimmed. Mr Lawson asked Sir Peter to consult industry and to consider foreign collaboration.

Sir Peter sent his reply to the government early this year. It included alternative collaboration proposals with the United States and with Europe, one of them earmarked for approval. A government decision based on Sir Peter's recommendations was expected at the end of last session, but the general election, and the appointment of a new Secretary of State for Energy, has pushed the likely date of the announcement back to the autumn.

The outline European agreement - it would be between the five national partners in the Superphénix licensing company SERENA and Britain - falls into three main sections, says $M$. Rapin.

- First, collaboration on research and
Arms control

\section{Washington}

THE meeting of the International Union of Geodesy and Geophysics at Hamburg next week will be given a demonstration of a prototype of a seismic station whose development has been sponsored by the Defense Advanced Research Projects Agency (DARPA) of the US Department of Defense. The system, which depends on a custom-designed blend of hardware and software to extract digital information from analogue seismic signals, was demonstrated on 13 July in Geneva to a meeting of the working group on seismic detection of nuclear explosions, one of the technical committees operated by the United Nations Committee on Disarmament whose objective is to improve the remote monitoring of existing and (perhaps) future treaties on nuclear tests.

The seismic analysis system consists of a specially-designed microprocessor with a memory capacity of 1 megabyte (MB) together with disk storage of $86 \mathrm{MB}$ and magnetic tape storage ad lib. Ordinarily, the system would be coupled to at least three local seismic detectors, but it is able to handle the output from seismographs sensitive at various frequencies.

The hardware has been developed by development towards a CDFR. This would probably be Superphénix II, already under development, and likely to be sited next to Superphénix I or nearby at Marcoule on the Rhone.

- Second, commercial collaboration between British and continental nuclear constructors, in relation to CDFR and future fast reactors.

- Third, cooperation on the plutonium fuel cycle. (Here, Britain believes its Dounreay reprocessing system is considerably in advance of the French.)

Unlike previous attempts at agreement, where the French were said to be asking a $£ 20-£ 25$ million entry fee, this time the draft agreement mentions no money. Payment will be "in kind", says Rapin. Thus, for example, when Superphénix II is built, the British will be expected to construct part of it. Other CDFRs should go up in other countries, also paid for by cooperation, but these would come after Superphénix II, Rapin believes. They are not part of the agreement.

Thus arguments about the siting of a CDFR in Britain would appear to be very premature - although reports in a British Sunday newspaper that a British CDFR might not be built in Dounreay have angered Scots people in the region, who have learned to love the breeder as a source of jobs, rare enough in Scotland. Considering the local environmental objections that are likely to be raised anywhere else in the country, that might be argument enough to place it there.

Robert Walgate

\title{
Remote seismic station on show
}

Sun Systems of Mountain View, California, and the software by the company called S-Cubed of San Diego. The total cost of the system is said to be less than $\$ 50,000$, which it is hoped (by DARPA and its two contractors) will make purchase attractive both to governments seeking an independent capability for monitoring seismic signals and to seismologists with a more academic interest.

The long-term aim at Geneva is that national governments will use such systems for recording seismic data, and will agree to supply these by means of the World Meteorological Organization's communications network to two international centres, in Moscow and Washington. In return, they will be able to interrogate the centres for data from the global network on any chosen events.

Part of the interest of the new device is that it shows how the US Government has kept up its interest in seismic detection since the ending of the nuclear test-ban negotiations in 1980 . To test the working of a global network, DARPA has recently established a Center for Seimic Studies near Washington, initially to use data gathered from seismic stations within the continental United States. 